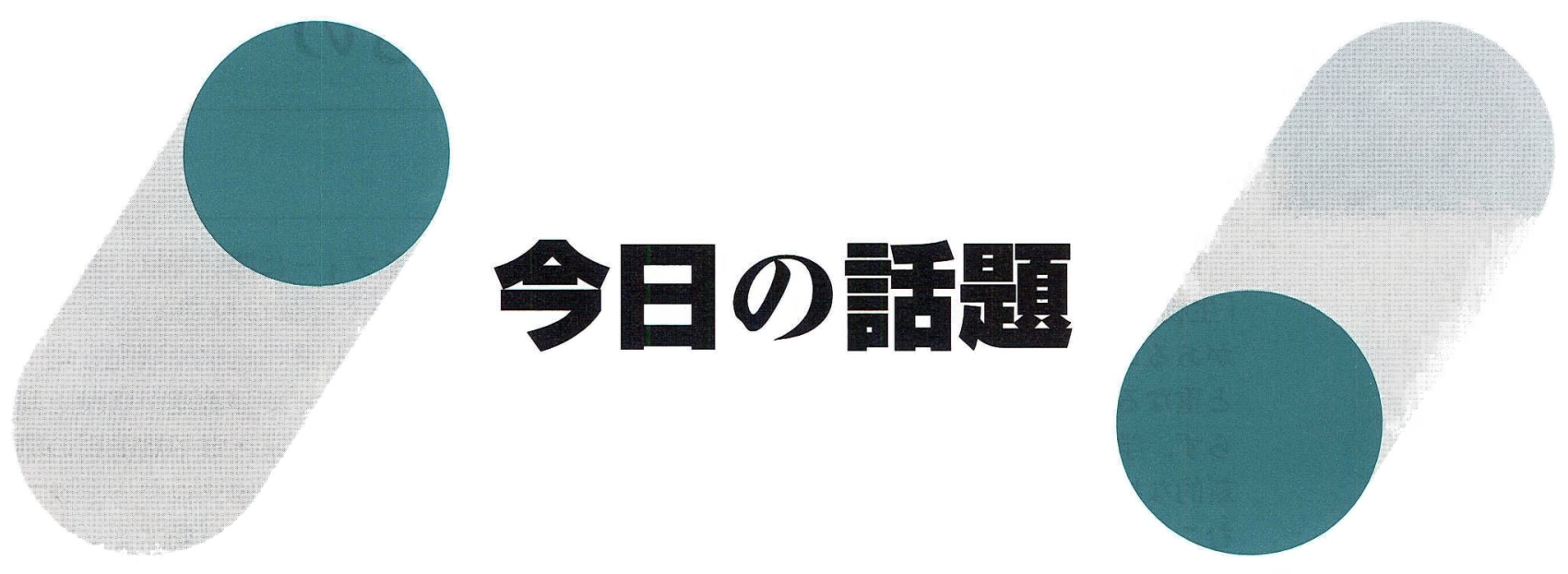

\title{
GPI アンカ一型タンパク質の脂質リモデリングとその意義 マイクロドメインへの組み込みに重要な役割. 細胞のがん化にも関与?
}

タンパク質の翻訳後修飾のタイプの一つに，グリコシ ルホスファチジルイノシトール（GPI）という糖脂質の 一種による修飾がある．細胞表層に存在する夕ンパク質 の一部は，GPIによって細胞膜に繋ぎ止められている. GPI があたかも錨のように作用することから，このよう なタンパク質は GPI アンカー型タンパク質と呼ばれる. 細胞膜は，均一な構造をしているわけではなく，物性の 異なる微小な領域がパッチ状に存在していることが最近 わかってきた。このような領域はマイクロドメインある いは脂質ラフトと呼ばれ，GPI アンカー型タンパク質は ステロールやスフィンゴ脂質とともに，マイクロドメイ ンを形成するむのの一つである。このようなマイクロド メインは，膜タンパク質の局在化やシグナル伝達などに 重要な役割を果たしている.

GPI の合成は小胞体で始まる（図 1).リン脂質ホス ファチジルイノシトール（PI）にグルコサミン，マン ノース, エタノールアミンリン酸, アシル基などが付加 し, 完成型 GPI 前駆体が合成される. 完成型 GPI 前駆体 は，トランスアミダーゼ複合体によってタンパク質の C 端側に転移される．その後，イノシトールの脱アシル化 が起こり，さらに脂質部分の変換が行なわれる．PIの $s n-2$ 位に付加している脂肪酸の多くは不飽和結合を もったものであるが，これが飽和型の脂肪酸に置き換え られる，生物種によっては，その後さらに，ジアシルグ リセロールがセラミドに変換されることがある。このよ うな脂質部分の変換は「脂質リモデリング」と呼ばれて いる(1,2).
では，脂質リモデリングはどのようなメカニズムで行 なわれ，またその生理的役割は何なのか？ 酵母細胞を 用いた研究がこれらの疑問の解明に大きく貢献した. 近 年, PI の $s n-2$ 位の不飽和脂肪酸を除去してリゾ PIにす るホスホリパーゼ $\mathrm{A}_{2}$ 活性にPER1 遺伝子が関与してい ることを，筆者らは明らかにした ${ }^{(3)}$ (図 2)。また，フリ ブール大学 (スイス) の Conzelmann 教授のグループ は, リゾ PI の sn-2 位に飽和脂肪酸を転移する活性に GUP1 遺伝子が関与していることを明らかにした ${ }^{(4)}$.

$P E R 1$ 遺伝子, GUP1 遺伝子を破壊した酵母株ではいず れも, 細胞膜に局在すべき GPI アンカー型タンパク質が 培地中に流れ出てしまうことがわかった。この理由は, 本来マイクロドメインに組み込まれるべき GPIアン カー型タンパク質が正しく組み込まれないためであっ た、これらの研究により，GPIアンカー型タンパク質の 脂質リモデリングは，GPIアンカー型タンパク質が正し くマイクロドメインに組み込まれるために重要な役割を 果たしていることが明らかになった.

哺乳類にもPER1 の相同遺伝子があり，ヒトPERLD 1 遺伝子は, per 1 遺伝子破壊株の表現型を相補した ${ }^{(3)}$. 興味深いのは, PERLD1 遺伝子の発現が胃がんや乳が んの細胞において元進していることである(5).また， GPI 合成系において, 完成型 GPI 前駆体をタンパク質に 転移するトランスアミダーゼをコードする遺伝子群のう ち，少なくとも 3 つががん遺伝子であることが報告され ている.さらに，現在知られている主要ながんマーカー のいくつかが GPI アンカー型タンパク質であることを 


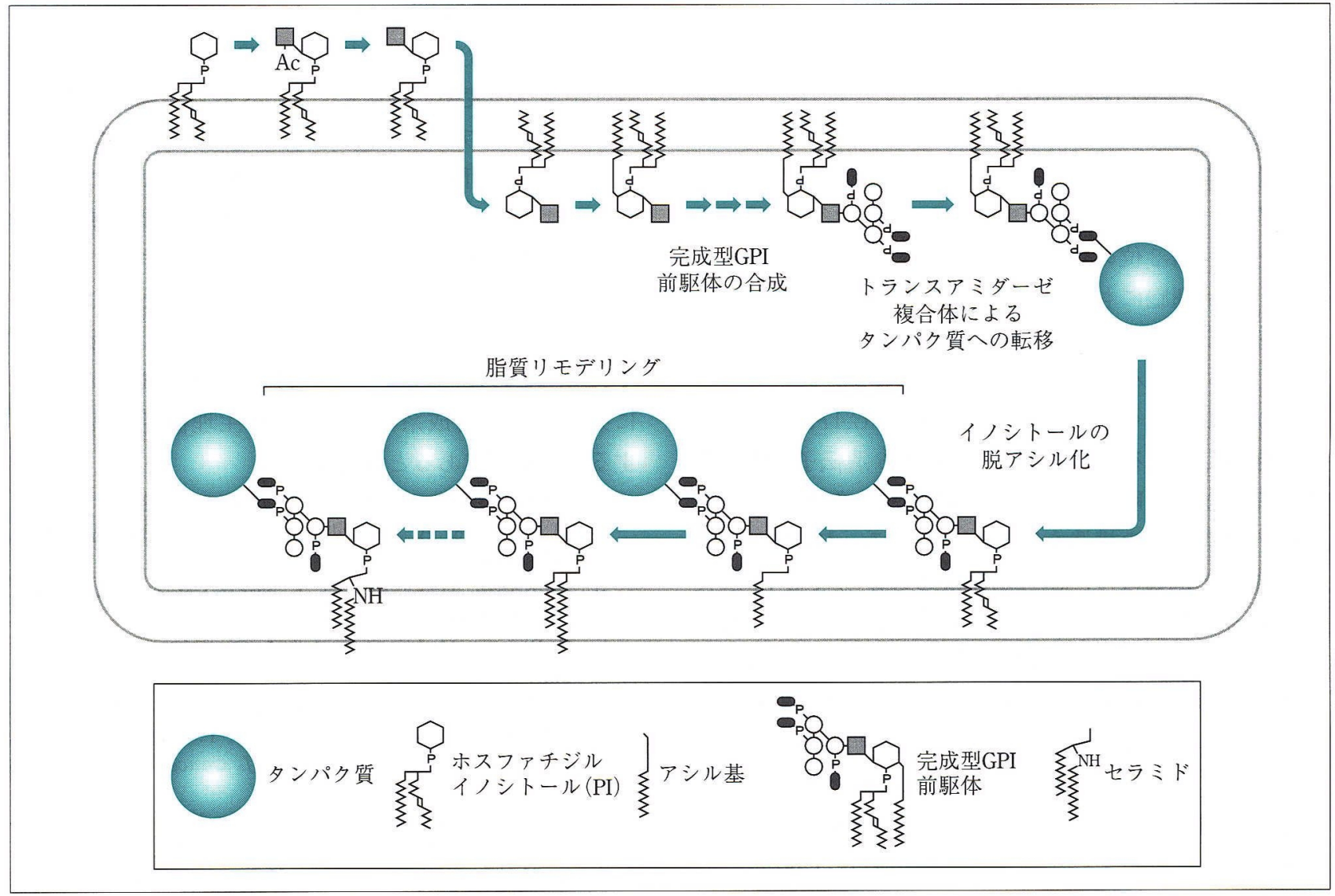

図 1 घ 小胞体における GPI アンカー型タンパク質の生合成系の概略

出芽酵母の例を示す.

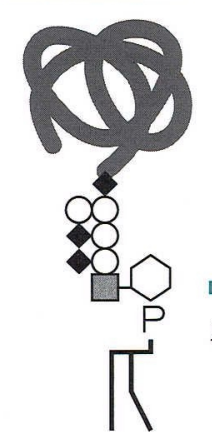

$s n$-2位に不飽和 脂肪酸をもつPI

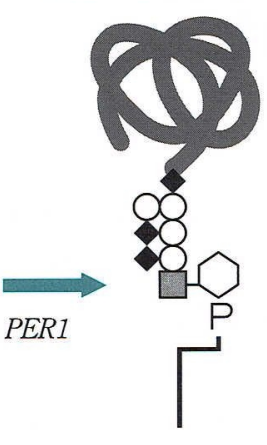

リソ゚PI
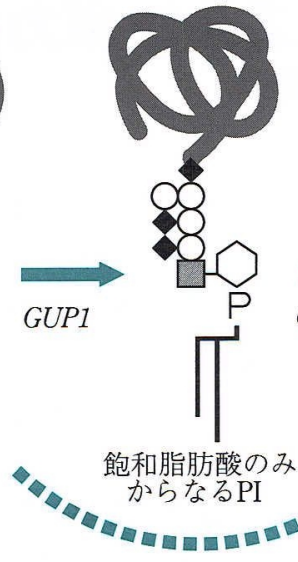

ジアシルグリセロール型
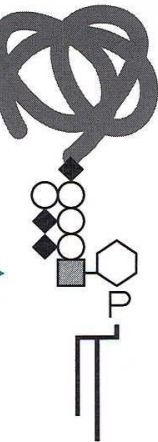

CWH43
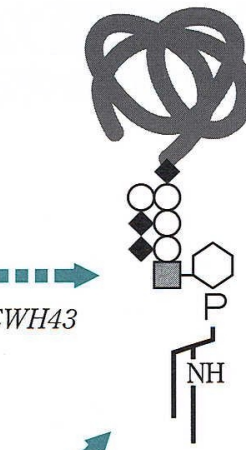

セラミド型
図 2 出芽酵母における GPI の 脂質リモデリング

$\mathrm{PI}$ のジアシルグリセロールの $s n-2$ 位に付加している不飽和脂肪酸は飽 和脂肪酸に置き換えられる．不飽和 脂肪酸の除去と飽和脂肪酸の再付加 に関与する遺伝子が，それぞれ PER1, GUP1 である.CWH43 遺伝 子は脂質部分をセラミド型に変換す る役割を担っているが，その直接の 基質は今のところ不明である.
考えあわせると，以下のようなことが考えられる.すな わち，GPI 合成系が異常になると，GPI アンカー型タン パク質が正しくマイクロドメインに組み込まれず，その
結果, 異常になったマイクロドメインはシグナル伝達を 正しく行なうことができなくなり，細胞ががん化する， というシナリオである. 
このように, がんとも深い関連がありそうな GPI の脂 質リモデリングであるが，哺乳動物の細胞においても， 上で述べた PERLD1 に加えて, PGAP2 (FRAG1 とも呼 ばれる ) 遺伝子が脂質リモデリングに関与していること を，阪大微研の木下教授のグループが明らかにした ${ }^{(6)}$. PGAP2 の変異細胞株の GPI アンカー型タンパク質の脂 質部分は, $s n-2$ 位の脂肪酸が失われたリゾ PIになって いた。酵母細胞にもPGAP2 に類似した遺伝子 CWH43 が存在するが，この遺伝子産物は 953 アミノ酸残基から なり，254アミノ酸残基からなる PGAP2 タンパク質よ りもかなり大きく，その $\mathrm{N}$ 端側のみが $P G A P 2$ タンパク 質に類似しているにすぎない. $C W H 43$ 遺伝子の機能を 調べるため，CWH43 の遺伝子破壊株を作製し，その GPI の脂質部分の構造を解析したところ, PGAP2 変異 株の場合とは異なり, 飽和脂肪酸のみからなる PI が大 半である一方, セラミド型の分子は検出されなかった. このことより，CWH43 遺伝子は，GPIアンカー型タン パク質の脂質部分をジアシルグリセロール型からセラミ ド型に変換する機能を有していることが明らかになった $(\text { 図 } 2)^{(7)}$. これまで，セラミド型への変換に関与する遺

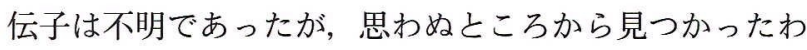
けである.このセラミド型への変換機能は, Cwh43p の

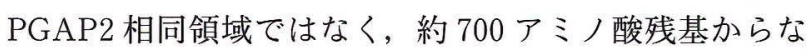
る C 端側の領域が担っていた.さらに,この C 端側領域
は哺乳類にも相同遺伝子が存在し（ヒトFLJ21511, マウ ス C130090K23），この遺伝子を酵母内で発現させるとセ ラミド型への変換活性を示した。これは，哺乳類にはセ ラミド型 GPI アンカー型タンパク質は存在しないとい う定説を覆す可能性を示唆する，興味深い結果である. ことによると, 哺乳類における糖脂質の構造と機能に対 する認識を大きく変える必要があるかも知れない.

GPI アンカー型タンパク質の脂質部分のセラミドへの 変換にどのような生理的役割があるのかは, 今後の課題 である.この役割の解明は，酵母のみならず，真核生物 に共通な GPI 合成系の全貌とその生理機能を明らかに する上で重要であると考えている.

1) P. Orlean \& A. K. Menon: J. Lipid Res., 48, 993 (2007).

2) M. Pittet \& A. Conzelmann:Biochim. Biophys. Acta, 1771, 405 (2007).

3) M. Fujita, M. Umemura, T. Yoko-o \& Y. Jigami : Mol. Biol. Cell, 17, 5253 (2006).

4) R. Bosson, M. Jaquenoud \& A. Conzelmann : Mol. Biol. Cell, 17, 2636 (2006).

5) M. Nezu, M. Nishigaki, T. Ishizuka, Y. Kuwahara, C. Tanabe, K. Aoyagi, H. Sakamoto, Y. Saito, T. Yoshida, H. Sasaki \& M. Terada:Jpn. J. Cancer Res., 93, 1183 (2002).

6) Y. Tashima, R. Taguchi, C. Murata, H. Ashida, T. Kinoshita \& Y. Maeda: Mol. Biol. Cell, 17, 1410 (2006).

7) M. Umemura, M. Fujita, T. Yoko-o, A. Fukamizu \& Y. Jigami: Mol. Biol. Cell, in press (2007).

(横尾岳彦, 地神芳文, (独) 産業技術総合研究所)

\section{両生類の最悪の病原菌カエルツボカビ 病原性，感染性，適応性の解明が急務}

[ツボカビ］というと，なんともユーモラスな形が想像 され, さらに [カエル とつくと, 少しも恐ろしい感じ はしない，そのカエルツボカビが，2006 年 12 月に日本 で初めて発見された。これを受けて，1力月後，急遽 16 の団体による「ツボカビ症侵入緊急事態宣言」が発表さ れた，以来，新聞各社で 1 面や社説でも取り上げられ， さらに, テレビのニュースはむとょり, ワイド番組にも, 「両生類の過去最悪の伝染病」として広く報道された。

そもそもカエルツボカビは, 1998 年にパナマとオース トラリアで，大量死したカエルから初めて発見され，翌 年に 1 属 1 種の真菌として登録された。 その後の遡及的 研究や, 加速度的な勢いで減少する両生類に関する調查 によって，世界的規模の両生類の絶滅，減少に関わる新
興病原体として捉えられ，2005 年 9 月ワシントン DC で の「両生類保全サミット」や 2006 年 8 月ドイッでの「野 生生物保全繁殖専門家集団総会」で, 最重要課題として 取り上げられた。このように，カエルッボカビは，アジ アを除く世界中で猛威を振るい，国際自然保護連合によ

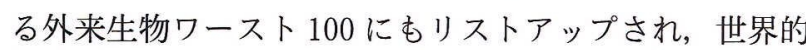
な監視が必要な病原体とされていた。 そのカエルツボカ ビがとうとう日本で発見されたのである。

カエルツボカビとは, ツボカビ門, ツボカビ目に属す る原始的な真菌の 1 種で, 学名を Batrachochytrium dendrobatidis という。属名 Batrachochytrium の “Batracho”はギリシャ語でカエルを，ツボカビを意味する “chytrium”の “chytr” (あるいはツボカビの chytrid) 


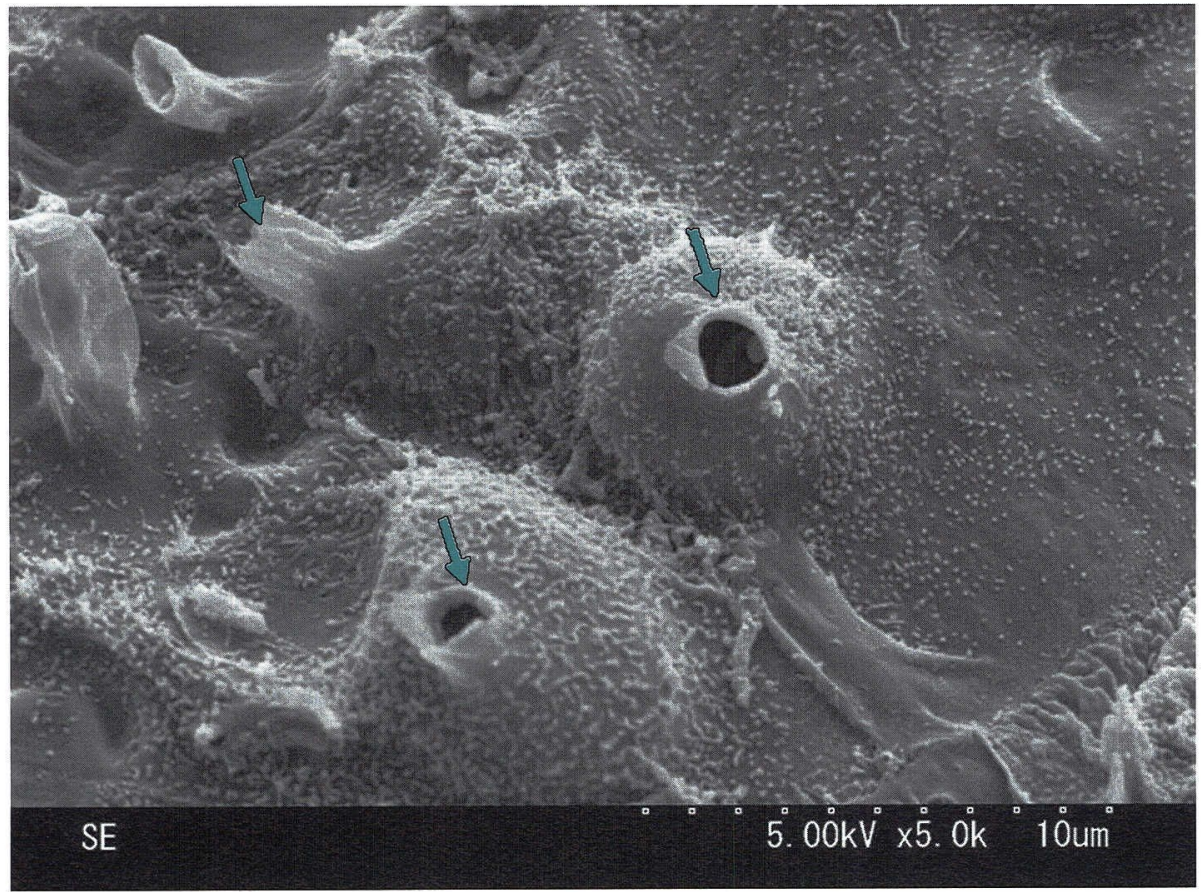

図 1曰日本で初めて確認されたカ エルのツボカビ症の走査電顕像

ッノガエル体幹部の皮膚の表面. ツ ボカビの遊走子囊がドーム上に皮膚 表面に隆起している. 矢印は放出 管. 皮膚表面には，多数の細菌が付 着している(皮膚のバリアーが破壊 されているため).
はギリシャ語の “chytridion”または “chutridion” ( 陶 器製の小型のツボ) に由来する。したがって，直訳すれ ばカエルッボカビ属となる．種名の “dendrobatidis”は ヤドクガエル属 (Dendrobates) の 1 種 (blue poison dart frog）からの分離株を用いて種の記載を行なった ことによる。しかし，カエルツボカビの宿主はヤドクガ エルに限られているわけではない.

ツボカビ類は一般的に土袞や淡水中に生息し, 分解菌 あるいは腐生菌としてキチン，セルロース，ケラチンと いった分解しにくい物質を利用している。具体的には花 粉粒, 昆虫の外骨格, 原生生物や微小無脊椎動物, 両生 類の皮膚，他種の真菌，草木や果実，水に浸かった枝な どの小片に付着あるいは寄生して栄養を吸収している.

脊椎動物に寄生する唯一のツボカビ類が B. dendrobatidis で，ケラチンを好み，生きているあるいは死んだ両 生類の皮膚に寄生し，そこに含まれているケラチンを利 用して発育する.

ツボカビの生活環は非常に単純で, 遊走子（カビの胞 子に相当）と遊走子囊（遊走子をはぐくむ袋）の 2 つの 形態しかない. ツボカビの遊走子震は球形から長球形 で，煙突のような放出管をむつ。遊走子囊は皮膚の表面 から放出管だけを突出させ，その蓋を外して遊走子を放 出する. ツボカビは真菌の中にあって, 唯一その生活環
に鞭毛をむつ遊走子をつくる．この鞭毛によって水中を 遊走して, 動物に感染する。このため, カエルツボカビ に水は不可欠である.

さて，カエルツボカビはヒトを含めた哺乳類，鳥類， 爬虫類や魚類には感染しないが, 多くの種類の両生類に 感染する。 2007 年現在, 200 種類以上に感染する（広宿 主域). また, 両生類の種類によって差があるが, 感染し て発症する之致死率が高く, $90 \%$ 以上も死亡する（高致 死率).さらに，ごくわずかな数の病原体に接触しただけ で感染が成立する（高感染性）といわれている，カエル ツボカビはたった 100 個の遊走子で, ある種類のカエル を死に至らしめる. そして，最も問題なのは，水を介し て遊走子が感染することで，水による広域な拡散が可能 となっている，このように高宿主性，高致死率，高感染 性であることから「過去最悪の伝染病」といわれている.

これまで述べたように, カエルツボカビは病原体とし てかなり危険な要素を備えていて, 世界中の両生類に影 響を与えているが，少し詳細にみてみると，その影響の 程度は地域によって異なっている.オーストラリアやパ ナマのように甚大な被害が見られるところと, 欧州のよ うに限定した国で，特定の種類の両生類のみの影響しか 確認されていないところむある。これは，それぞれの地 域に生息する両生類のカエルツボカビへの感受性の違い 
とカエルツボカビを取り巻く環境（気候, 土壤, 植生な ど）によるものと考えられる。

日本では, 2007 年 7 月現在で, 飼育下の外来種および 在来種の $30 \%$ 以上からカエルツボカビが検出されてい る. また，野外に生息している両生類が少なからず陽性

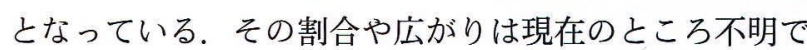
あるが (環境省が調查中), すでに野外に拡散しているも のと推察される.この状況下で，今後日本ではごのよう なことが起こりうるのか, これを予想するためには, い くつか明らかにしなければならないことがある。すなわ ち,

(1)日本のカエルは, カエルツボカビに対してどの程度 の感受性を有しているのか.

(2)カエルツボカビのタイプによる病原性に違いはある のか（国内で検出されたカエルツボカビを遺伝子学的に 解析すると, いくつかのタイプに分けられ, 無症状の両 生類から高率に検出されるタイプが存在する).

(3)カエルツボカビは日本の自然界で長く生存できるの 加.

これらを明らかにしない限り, 日本におけるカエルッ ボカビ対策のシナリオを描くことはできない.

2006 年 12 月に国内で初めてカエルツボカビが発見さ れ，7 カ月目を迎えた. 発見当初から, 国内にはカエルツ ボカビの専門家はいなかった，国内初（アジア初）のツ ボカビ症を発見した宇根自身も, 獣医病理学を専攻し,
感染症, 特に野生動物やエキゾチックアニマルの感染症 を研究テーマとしていて, カエルツボカビはもよより, カエル自体の病性鑑定も稀なことだった. まさか, カエ ルが研究室に溢れ，連日のように剖検に追われ，手がけ た両生類の数が 500 を優に上回ることになるなど予想だ にしなかった. 微生物学的側面からの研究を担っている 黒木は, 公衆衛生学, 微生物学を専門としてサルモネラ, レジオネラ, クリプトスポリジウムなどを得意としてい るが, 両生類の飼育・繁殖を趣味としていたことから, カエルの種類の見分け方, 生態などに多少の心得がある 程度である. また，共同研究者の一人で，分子生物学的 側面からの研究, 検査を担当している国立環境研究所五 筒公一先生は, 豊富な経験（カエルツボカビではない） と最先端の分子生物学的技術や知識をお持ちであるが, 実はダニ学を専門としている. カエルツボカビ発見を機 に, ここに紹介した研究者だけではなく, 生態学者, 多 くの自然保護団体など, 各分野の専門家がそれぞれの知 識と技術を持ち寄って, 日本の生態系および生物多様性 の保全という目的のために，日夜活動している.

カエルツボカビ自体も, 9 年前に確認された病原体で, まだまだ不明なことが多く, 混沌としたなか, 手探りで 研究・調査が進められているのが実情だ.

$($ 宇根有美 $* 1$, 黒木俊郎 $* 2, * 1$ 麻布大学獣医学部, $* 2$ 神奈 川県衛生研究所）

\section{人工塩基対による遺伝情報の拡張技術 新しい㙨能性核酸や核酸医薬の創出に期待}

DNA はなぜ 4 種類の塩基からできているのだろう か? これらの塩基は, $\mathrm{A}$ と $\mathrm{T}$, そして $\mathrm{G}$ と $\mathrm{C}$ がそれぞ れ塩基対を形成する。この塩基対形成による相補性が生 命のセントラルドグマ（複製・転写・翻訳）の基本法則 である. したがって, 塩基対としてのペアを考慮すると $2 \times n$ 個の種類の塩基が必要になる，それでは， 6 種類の 塩基から成る DNA は遺伝子としてありえるのだろう か? 最近, 第三の塩基対 (5 番目, 6 番目の塩基) を人 工的につくり出し，これを組み込んだ DNA を遺伝子と して働かせる研究が進んでいる.

この知的興味に加えて, 人工塩基対の研究は, 従来の 組換え型の遺伝子操作技術に代わる次世代のバイオ技術
としても位置づけられている，人工塩基対を組み込んだ DNA が鋳型として複製や転写で機能すれば, 新たな塩 基やその誘導体を DNA や RNA の特定部位に導入でき る.また，人工塩基を含む新たなコドンを用いた翻訳に より, 非天然型アミノ酸のタンパク質中への導入む可能 になる．したがって，人工塩基対技術により，天然には ない構成成分を組み込んだ新機能の核酸や夕ンパク質の 創出が期待される.

この技術を達成するためには, 複製・転写・翻訳にお いて, A-T (U) と G-C の天然型塩基対と同等の選択性と 効率を有する人工塩基対を開発する必要がある．たとえ ば, DNA ポリメラーゼによる複製では, 鋳型鎖 DNA 中 


\section{今日の話題}

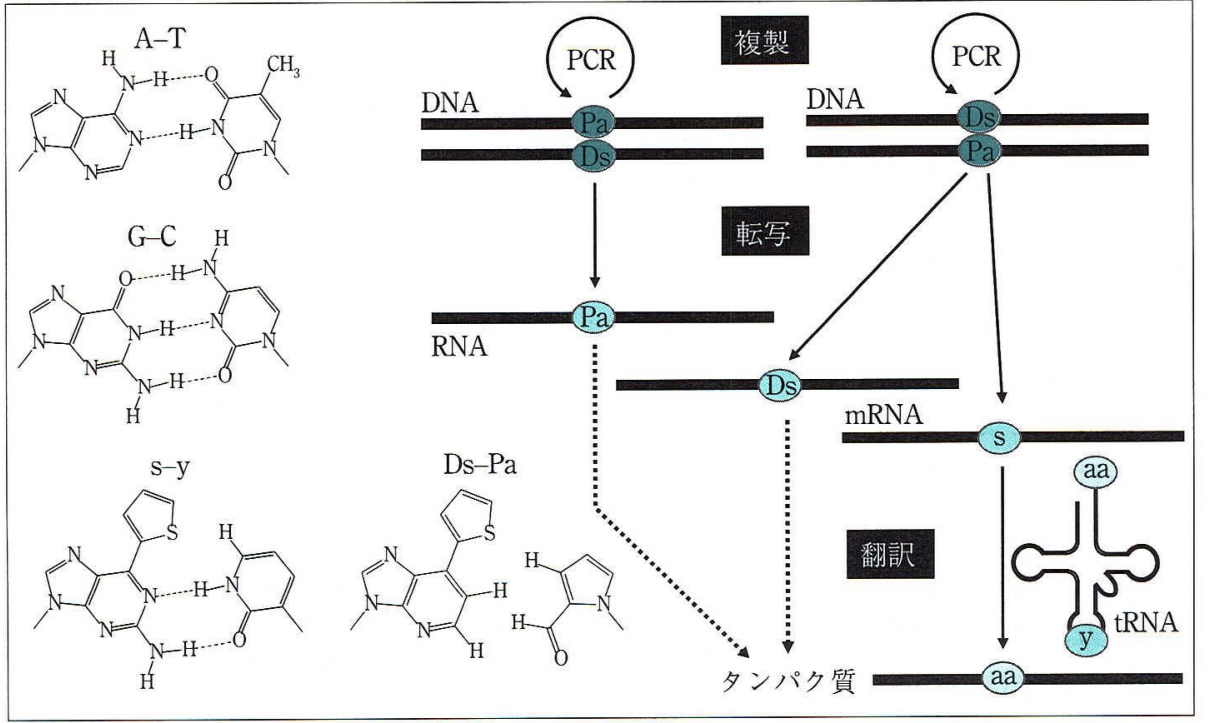

図 1 - 人工塩基対による遺伝情報 の拡張

天然型の A-T, G-C の塩基対と人工 の s-y, Ds-Pa 塩基対のそれぞれの 構造 (図左側). Ds-Pa 塩基対は複 製と転写で機能し, s-y 塩基対は転 写と翻訳で機能する.さらにPaを 鋳型にして s む転写により RNA 中 に取り込ませることができる。これ らの人工塩基を組み合わせることに より，複製・転写・翻訳のすべてに おいて遗伝情報の抎張が可能になる (図右側).
の人工塩基に対して，対合する人工塩基のみが基質とし て相補鎖 DNA 中に取り込まれなければならない，反対 に，鋳型鎖 DNA 中の天然型塩基に対しては人工塩基が その相補鎖 DNA 中に取り込まれてはならない，人工塩 基対の研究は, 1989 年の S. A. Benner らの論文に始ま り，現在までに数十種類の人工塩基対が報告されてき た ${ }^{(1 \sim 3)}$. しかし，ほとんどの人工塩基対は実用化レベル の性能には達していなかった，その中で筆者らは, 試行 錯誤の末， 2002 年に転写と翻訳で機能する人工塩基対 (s-y 塩基対と名づけた $)^{(4)}$ ，そして 2006 年には複製と転 写で機能する人工塩基対（Ds-Pa 塩基対）の開発に成功 した (5) (図 1).

$\mathrm{s}-\mathrm{y}$ 塩基対は天然型塩基対と異なる水素結合様式でで

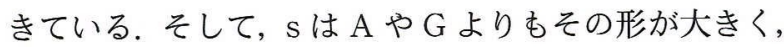
逆に $\mathrm{y}$ は T や Cよりもわずかに小さくなるようにそれ ぞれ設計された。 s を組み込んだ鋳型 DNA を用いた転 写で，基質 $\mathrm{y}$ は部位特異的に RNA 中に取り込まれた.

さらに，この転写を試験管内の翻訳系と組み合わせるこ とにより，非天然型アミノ酸をタンパク質中に取り込ま せることもできた ${ }^{(4)}$. しかし， s-y 塩基対は複製におい てはその選択性に問題があった， s-y 塩基対を組み込ん だ DNA を用いて試験管内の複製である PCR を行なう と，10 サイクルの PCR で増幅された DNA は $50 \%$ 以上 の $\mathrm{s}-\mathrm{y}$ 塩基対が天然型の塩基対に置き換わってしまっ た．複製された DNA も次の複製の鋳型になるため，人 工塩基に対して天然型塩基が少しでも取り込まれてしま うと,これが増幅されてしまう。したがって, 複製では
さらに選択性の高い人工塩基対を開発する必要があっ た.

そこで筆者らは，PCR に使用できる人工塩基対の開 発を目指してさらに改良を続けた。そしてでき上がった 人工塩基対が Ds-Pa である(5). 実は，水素結合をもたな い塩基対も複製で機能することが最近わかってきた ${ }^{(1)}$ そこでこの人工塩基対では, s-y における塩基対面の水 素結合に関わる元素や置換基を除くことにより，水素結 合性の天然型塩基との対合を抑えるようにした。ささら に，Paにはその骨格に 5 員環構造を用いることにより， y よりもさらに形を小さくして, Ds との形状適合性を 高めた。この Ds-Pa 塩基対を組み込んだ DNA を用いて 10 サイクルのPCRを行なったところ，増幅された DNA 中には 99\%以上 Ds-Pa 塩基対が保存されていた. Ds-Pa 塩基対は転写においても相補的に機能し，鋳型 DNA 中の Ds に対して基質 $\mathrm{Pa}$ が，また $\mathrm{Pa}$ に対しては 基質 Ds がそれぞれ RNA 中に取り込まれた。さらに， ビオチンなどの機能性の置換基を予結合させた $\mathrm{Pa} の$ 修飾基質も，転写により RNA 中に取り込ませることが できた ${ }^{(5)}$. これに加えて，鋳型 DNA 中の $\mathrm{Pa}$ に対して は, 先の人工塩基 $\mathrm{s}$ の基質も, 転写により RNA 中に選 択的に取り込まれることがわかった ${ }^{(6)}$.

現在，Ds-Pa 塩基対を用いた翻訳の実験む進めている が，筆者らが開発した人工塩基対を組み合わせると複製 から翻訳までの遺伝情報の拡張がすでに可能になってい る（図 1)。すなわち，Ds-Pa 塩基対を組み込んだ DNA を PCR で増幅し，Pa を含む側の DNA 鎖を鋳型にした 
転写で mRNA 中に $\mathrm{s}$ を組み込むことができる。この $\mathrm{s}$ を含む mRNA とアンチコドンに $\mathrm{y}$ を含む tRNA（これ は $\mathrm{s}$ を組み込んだ鋳型 DNA から転写で調製できる）を 用いて翻訳を行なうことにより，タンパク質中への非天 然型アミノ酸の導入が可能になる。

Ds-Paのように複製においてむ機能する人工塩基対が 開発されたことから，A-T と G-C 以外の塩基対を含む 遺伝子が存在する可能性も出てきた，同時に，人工塩基 対技術の実用化研究む始まった．特に本技術による新規 機能性核酸の創出が期待される：筆者らは，蛍光性の人 工塩基を機能性の核酸断片の特定部位に導入することに より，核酸の局部構造の解析技術や診断・治療を目指し た核酸医薬の開発を進めている ${ }^{(6 \sim 7)}$. 一方，タンパク質 中に非天然型アミノ酸を導入する技術の開発において は，異なる手法によるオリジナルな研究を進めている トップクラスの研究者が国内に点在している ${ }^{(8 \sim 10)}$. これ らの研究者が結集すれば，世界に先駆けてセントラルド グマの合成生物学を基盤とする革新的なバイオ技術を生
み出せるのではないだろうか.

1) E. T. Kool:Curr. Opin. Chem. Biol., 4, 602 (2000).

2) A. A. Henry \& F. E. Romesberg:Curr. Opin. Chem. Biol., 7, 727 (2003).

3) I. Hirao:Curr. Opin. Chem. Biol., 10, 622 (2006).

4) I. Hirao, T. Ohtsuki, T. Fujiwara, T. Mitsui, T. Yokogawa, T. Okuni, H. Nakayama, K. Tako, T. Yabuki, T. Kigawa, K. Kodama, T. Yokogawa, K. Nishikawa \& S. Yokoyama: Nature Biotechnol., 20, 177 (2002).

5) I. Hirao, M. Kimoto, T. Mitsui, T. Fujiwara, R. Kawai, A Sato, Y. Harada \& S. Yokoyama : Nature Methods, 3, 729 (2006).

6) M. Kimoto, T. Mitsui, Y. Harada, A. Sato, S. Yokoyama \& I. Hirao: Nucleic Acids Res., in press.

7) I. Hirao : BioTechniques, 40, 711 (2006).

8) D. Kajihara, R. Abe, I. Iijima, C. Komiyama, M. Sisido \& T. Hohsaka : Nature Methods, 3, 923 (2006).

9) H. Murakami, A. Ohta, H. Ashigai \& H. Suga : Nature Methods, 3, 357 (2006).

10) N. Hino, Y. Okazaki, T. Kobayashi, A. Hayashi, K. Sakamoto \& S. Yokoyama:Nature Methods, 2, 201 (2005).

(平尾一郎, 理化学研究所ゲノム科学総合研究センター)

\section{植物といえば光合成？ 寄生植物の光合成能䘫失とフィトクロムの变異の解析からわかること}

「植物ってなんだ?」との問いに，「光合成を行なう生 物」という答えが返ってくる可能性は高いだろう. 実際, 光合成は地球上の生命を支える上で最む重要な生体反応 である，ところが，自然界には光合成を行なわない植物 が多く存在する，このような植物は，その出現の過程で 独立栄養性から再び従属栄養性へ之進化した，要するに “光合成能を捨てた”植物である，むちろん，これらの植 物が能動的に光合成をやめたわけではない，他の生物か ら栄養を得る機構を獲得したことで，光合成能維持のた めの選択圧が劇的に下がった結果，光合成に関わる遺伝 子が変化（欠損や偽遺伝子化）し，光合成能を失った之 考えられる．寄生植物はこのような植物の代表例であ り, 光合成能を失っていない半寄生植物と光合成能を完 全に㳖失した全寄生植物に分類される.

さらに，光は植物に光合成のエネルギーとして利用さ れるだけではなく，環境変化を知るためのシグナルとし ての役割ももつ. プラスチドは光を感知しないと葉緑体 へと成熟できないため，暗所で育てた植物はもやしにな る. 光があってはじめてなじみある緑の植物が育つが,
この際の光センサーが光受容体タンパク質である。これ までに，数種の光受容体ファミリーが明らかにされてお り，光合成に最も有効な赤色光の受容体がフィトクロム である(1). 光合成を効率よく行なうことは，植物にとっ ての死活問題である．たとえば，よく知られている避陰 反応では，植物はフィトクロムを用いて赤色と遠赤色光 の比を検知し, 赤色光の多いほう（日向）へ茎を伸ばす. さらに，発芽や花芽の形成あるいは概日時計など，光合 成に直接関係のない事象むフィトクロムに制御されてい ることがわかっている。

フィトクロムがどのような分子機構でシグナルを伝え ているかについては，未だ不明な点が多い，モデル植物 であるシロイヌナズナには，フィトクロム A (phyA) か らフィトクロム $\mathrm{E}(\mathrm{phyE})$ まで 5 つの分子種が存在して いることがわかっている．このうち phyA は遠赤色光に 対する光応答を担う唯一のフィトクロムである。 マイク ロアレイ解析より phy A が遠赤色光だけでなく初期の 赤色光応答む担っていることが明らかになり，この特殊 な分子種の重要性が認識されつつある(2). 


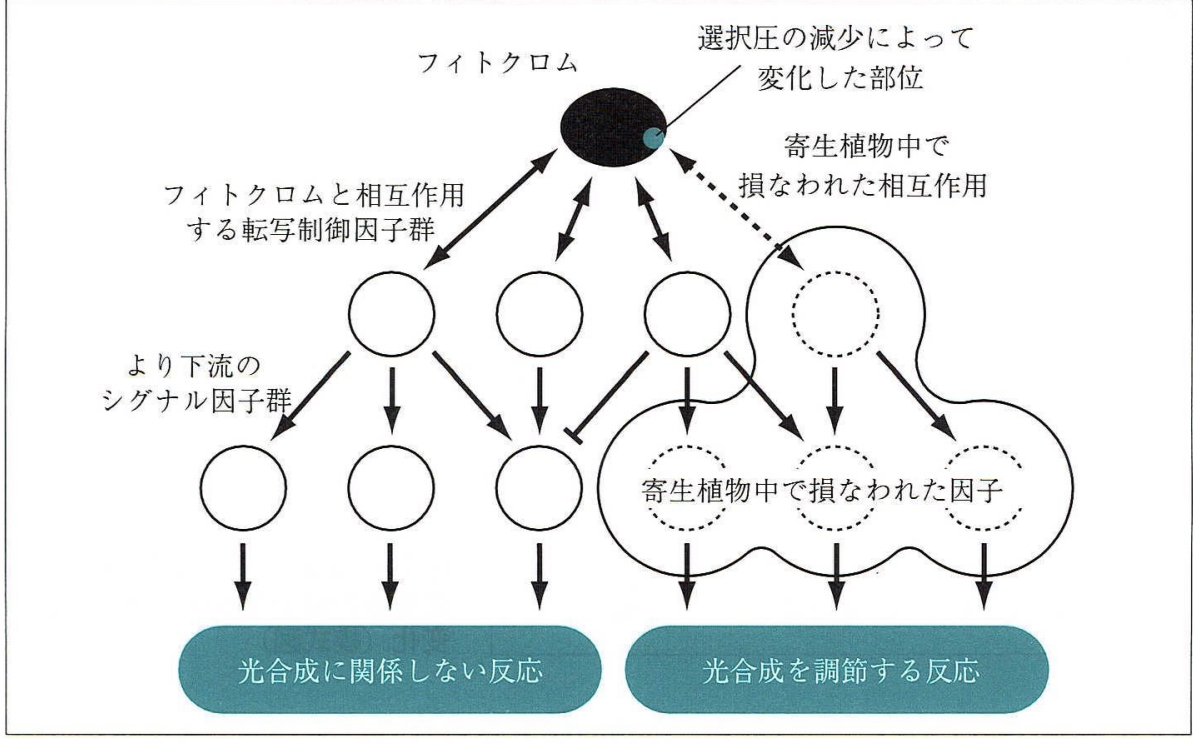

図 1 『寄生植物中で起こりうる フィトクロムからのシグナル伝達 経路の変化
さて, 光合成能を失った植物でフィトクロムはどのよ うに働いているのだろうか？ 筆者らは，全寄生植物に おいてフィトクロムからのシグナル伝達経路に存在しう る変化に着目し, 以下の仮定に基づいて研究を行なっ た.

(1)全寄生植物では光合成に関わる遺伝子は欠損してい るか偽遺伝子化している：この仮定を端的に支持する のは，全寄生植物においては光合成器官である葉がない という事実である。したがって，葉の分化を誘導する遺 伝子が発現していないことは容易に類推できる，実際 に，全寄生植物のプラスチドゲノムでは多くの光合成関 連遺伝子が損なわれている(3).

(2)フィトクロムは複数の因子と相互作用する：フィ トクロムは翻訳後も発色団の結合, シグナルペプチドの 切断，あるいはリン酸化など種々の制御を受ける. また， フィトクロム相互作用因子群や青色光受容体であるクリ プトクロムなどの多様なタンパク質との相互作用が実験 的に示されている.

(3)フィトクロムは高い選択圧を受けている：植物間 のフィトクロムの相同性は非常に高く，しかも光合成の 制御だけではなく植物の生活環のすべてを左右するの で，この遺伝子が欠損している植物は未だ報告がない．

これらの仮定を統合すると次のようになる，全寄生植 物では光合成に関わる遺伝子が発現しておらず，これら の一部は共通の発現制御を受けている可能性が高い.こ の制御機構に特異的に働く制御因子は, 下流の遺伝子と
同様に発現していない，その制御因子が phyA との相互 作用によって活性調節を受けているとすると，この制御 因子との相互作用が失われた全寄生植物中の phyA に おいては相互作用部位における選択圧が減少し,アミノ 酸配列に変化が生じる（図 1).

この仮定を検証するために，筆者らは全寄生植物ヤセ ウツボ (Orobanche minor) より PHYA 遺伝子のクロー ニングを行なった.すると，すべての光合成植物の phyA で保存されているアミノ酸のうち, 26 個所むの部 位がヤセウツボの phyA (OmphyA) では保存されてい なかった。この OmphyA をGFP との融合タンパク質 としてシロイヌナズナの細胞で発現させたところ, フィ トクロムに特徴的な光依存的核移行が確認され, 多数の アミノ酸の置換にもかかわらず核へシグナルを伝達する 機能は保持されていることがわかっだ(4).

変異個所のうちの一つは, 発色団結合ドメイン中にあ る 229 番目のグルタミン酸がグルタミンに置換されてい た。このグルタミン酸がリジンに置換されている eid4 というシロイヌナズナの変異体は, 光に対する感受性や phyA の分解, 核以降の速度が野生株のものと異なって いる(5). OmphyA における 229 番目のグルタミン酸が グルタミンへ変化していることが, 光合成能の亦失とど のように関わっているのかについて興味がもたれる。

ハーバード大の Mathews らは, 多くの寄生植物種が 属しているハマウツボ科の系統樹を $P H Y A$ 遺伝子の部 分配列を用いて作成した。この科には，全寄生性，半寄 


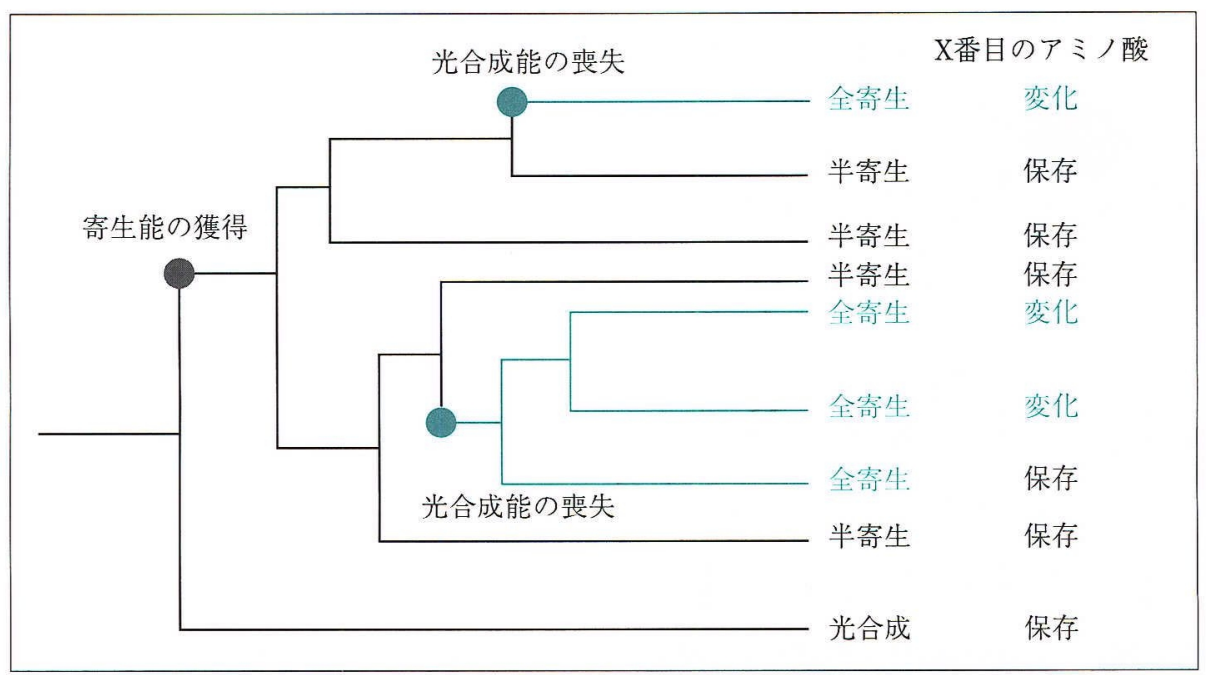

図 2 - PHYA 遺伝子を用いた寄 生植物の分子系統樹とアミノ酸の 変化（模式図）
生性, および寄生性でない植物が属しており, PHYAの 配列による分子系統樹によって，これまで他の配列では 判別できなかった系統関係を明らかにすることができ た (6). この系統樹から, 寄生能の獲得は八マウッボ科の 進化の過程で 1 回だけ起こり, その後, 独立に数回, 光 合成能を亦失したことが示された，筆者らは，Mathews らによって報告された部分配列を詳細に検討することに よって, 寄生性でない植物および半寄生植物では完全に 保存されているアミノ酸が, 独立に進化した全寄生性植 物では共通に置換されている例があることを見いだして いる (図 2, 未発表).このアミノ酸は $\mathrm{N}$ 末端側の光シグ ナル伝達ドメイン中に存在しており, 今後, このアミノ 酸が光合成の制御に果たす役割についての解明が期待さ れる。

このように, 非光合成植物中のフィトクロムは部分的 に機能が損なわれた変異体として扱えることが示されつ
つある．植物の研究を行なうにあたり, 変異体のスク リーニングは運や労力を要し，原因遺伝子の同定に至る までには膨大な時間がかかる，寄生植物のように進化的 に分子の機能を変化させてきた植物は, 高等植物におけ る生理反応の分子機構を明らかにする上で, 非常に重要 な遺伝資源であると考えられる。

1) F. Nagy \& E. Schäfer:Annu. Rev. Plant Biol., 53, 329 (2002).

2) J. M. Tepperman, Y.-S. Hwang \& P. H. Quail : Plant J., 48, 728 (2006).

3) R. A. Bungard: BioEssays, 26, 235 (2004).

4) C. Trakulnaleamsai, A. Okazawa, C.-I. An, S. Kajiyama, E. Fukusaki, K. Yoneyama, Y. Takeuchi \& A. Kobayashi : Biosci. Biotechnol. Biochem., 69, 71 (2005).

5) M. Dieterle, D. Bauer, C. Büche, M. Krenz, E. Scäfer \& T. Kretsch : Plant J., 41, 146 (2005).

6) J. R. Bennett \& S. Mathews: Am. J. Bot., 93, 1039 (2006). (岡澤敦司, 大阪大学大学院工学研究科)

\section{酵母を使ってプリオン病を理解する プリオン凝集体に感染力のあることを実証}

生体内における遺伝情報を核酸が担うことは疑うこと のない事実である。しかし，プリオン病においては“夕 ンパク質”が遺伝物質となる. プリオン病はウシの海綿 状脳症（狂牛病・BSE）やヒトのクロイツフェルト・ヤ コブ（CJD）病などを含む神経変性疾患の一つであり， 近年では，狂牛病を患ったウシの肉をヒトが食してプリ オン感染したことによる新型 CJDの発生が大きな社会
問題となった。

1982 年, 米国のプルシナー博士は, プリオン病の原因 因子としてプリオンタンパク質を同定した(1). これまで の生物学の常識に反し, ウイルスなどの核酸ではなく “タンパク質”がプリオン病の感染源であるとする「プリ オン仮説」は大きな反響を呼び,一部の研究者からは激 しく紏弾された。はたして，“プリオンタンパク質”に 


\section{今日の話題}

よってプリオン病はひき起こされるのだろうか？この 2,3 年の間,「プリオン仮説」に関する研究は急速な展開 を見せ，その正当性が現在，証明されつつある。つまり， 1997 年にプルシナー博士がノーベル生理学・医学賞を 受賞してから,「プリオン仮説」の証明には何とさらに約 10 年の年月を要したのだった。

「プリオン仮説」が一部の研究者から批判される理由, つまりその最大の欠点は，きわめて単純明快なもので あった，それは，精製したプリオンタンパク質の凝集体 を正常な野生型マウスへ注入しても，そのマウスはプリ オン病を発症しないことにあった。これは，プリオンタ ンパク質がプリオン病の原因物質ではない(つまり,「プ リオン仮説」が間違っている）ことを意味するのか，ま たは，in vitro で作製したプリオンタンパク質には “何 か”が欠けていて本来感染力をもつはずのプリオンタン パク質が感染力をもっていないのか？ プルシナー博士 がノーベル賞を取った後も,「プリオン仮説」の真偽を決 定づける証拠はなかった。

筆者らは「プリオン仮説」を検証すべく, 酵母プリオ ン $\left[P S I^{+}\right]$の系 ${ }^{(2)}$ 用いて研究を行なってきた。哺乳動 物のプリオンタンパク質とアミノ酸配列の相同性はない ものの, 酵母にも哺乳動物のプリオンタンパク質と似た 振る舞いを示すタンパク質が存在し，それらは“酵母プ リオン”之呼ばれている. 酵母プリオンはその研究材料, すなわち酵母の扱いやすさから，これまでプリオン病の 伝播機構の解明に大きな役割を果たしてきた。筆者ら は，翻訳終結因子 Sup35 が凝集することでプリオン様 表現型を示す $\left[P S I^{+}\right]$の系を用い，まず高度に精製した 可溶型および凝集型Sup35 タンパク質を酵母の中へ効 率よく直接導入する新たな手法の開発に着手した（図 1).この手法を開発することによって, 䤉母プリオン $\left[P S I^{+}\right]$の系では，プリオン感染実験を約 1 週間という短 期間で行なうことが可能となり，マウスなどの哺乳動物 を用いた実験系に比べて研究期間を大幅に短縮すること ができた。

その結果, 可溶型 Sup35 タンパク質にはプリオン感 染力はないが, 凝集型 Sup35 タンパク質はプリオン感 染力を示すことが明らかとなった ${ }^{(3)}$. しかむ，筆者らの 方法では $10 \mu \mathrm{M}$ 程度の Sup35 凝集体で，ほぼ $100 \% の$ 効率で野生型酵母をプリオン化させることに成功した. この結果は, Sup35 凝集体がプリオン感染源であること を直接証明するものである.

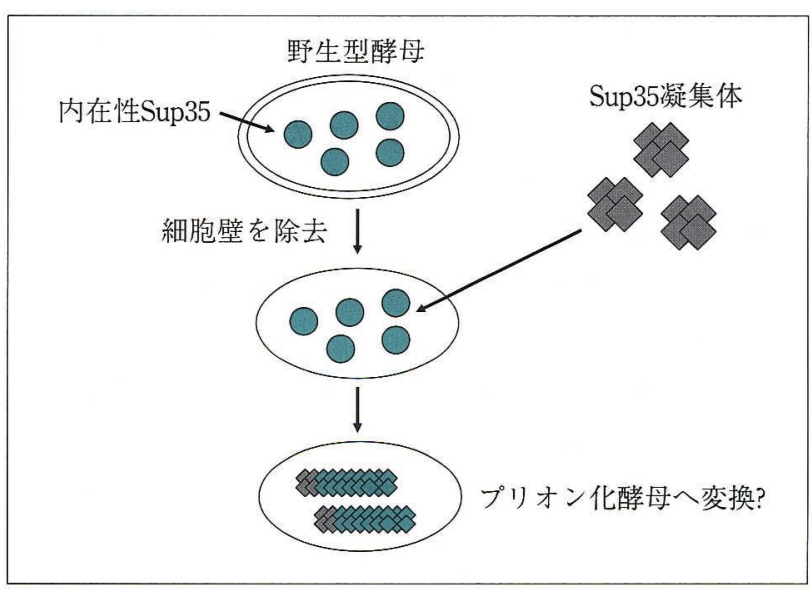

図 1 -Sup35 タンパク質凝集体を野生型酵母の中へ直接導入 する方法の概略

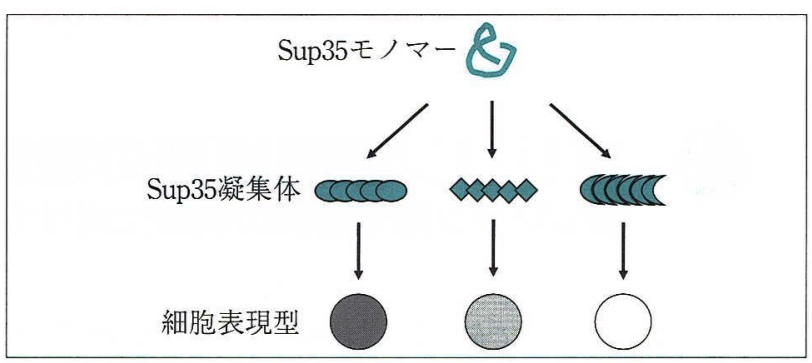

図 2 【 異なるコンフォメーションをもつ Sup 35 凝集体は異 なる細胞表現型を導く

また, プリオン病においては, 同じアミノ酸配列から なるプリオンタンパク質から，異なる症状が存在すると いう「プリオン株の存在」が古くから知られていた。こ の「プリオン株の存在」は, プリオン仮説と相容れない ものであろうか？ 筆者らは，まったく同じアミノ酸配 列からなるが異なるコンフォメーションをむつSup 35 凝集体を創製し，それらを先の手法で野生型酵母へ直接 導入したところ，それぞれで得られたプリオン化酵母が 異なる細胞表現型を示すことを見いだした（図 2) ${ }^{(3)}$. こ の結果は，プリオン凝集体のコンフォメーションの差異 がプリオン株の表現型を決定する物理的基盤になってい ることを示しており,「プリオン株の存在」が「プリオン 仮説」と両立することを証明するむのである ${ }^{(3,4)}$.

その後の 2004 年以降, 精製したヒトプリオンタンパ ク質からなる凝集体を変異型マウスや野生型ハムスター に注入し，プリオン病を発症させることができたという 実験結果が異なる研究グループから相次いで報告され た(5 7). これまでの研究では, 精製ヒトプリオンタンパ 
ク質凝集体は感染力を示さなかったのだが，それは，プ リオンタンパク質の「真に感染力のある凝集体」をうま くつくり出すことができなかっただけなのかも知れな い. 今後, さらに感染力の高いプリオン凝集体がつくり 出される可能性むある. いずれにしても, どうやら, プ リオンタンパク質はプリオン病の原因物質であったよう だ.

しかし，依然として私たちは，どのような特別な「形」 をしたプリオン凝集体が強い感染力をもち，どのような メカニズムによってそれが伝播していくのかをほとんど 知らない. 今後, これらを解明することによって，プリ オン病の有効な治療薬開発への道が拓けることが期待で きる.また，これまでの歴史が示しているように，プリ オンタンパク質の凝集機構や伝搬機構に関する研究は, タンパク質のミスフォールディングが関わる他の神経変
性疾患研究の発展にも多大な貢献をしてきている，今 後, プリオン研究をさらに発展させることによって, 神 経変性疾患研究全体を推進させることが期待される.

1) S. B. Prusiner, M. R. Scott, S. J. DeArmond \& F. E. Cohen : Cell, 93, 337 (1998).

2) M. F. Tuite \& N. Koloteva-Levin:Mol. Cell, 14, 541 (2004).

3) M. Tanaka, P. Chien, N. Naber, R. Cooke \& J. S. Weissman : Nature, 428, 323 (2004).

4) M. Tanaka, S. Collins, B. Toyama \& J. S. Weissman : Nature, 442, 585 (2006).

5) G. Legname, I. V. Baskakov, H. B. Nguyen, D. Riesner, F. E. Cohen, S. J. DeArmond \& S. B. Prusiner : Science, 305, 67 (2004).

6) J. Castilla, P. Saa, C. Hetz \& C. Soto : Cell, 121, 195 (2005).

7) N. R. Deleault, B. T. Harris, J. R. Rees \& S. Supattapone : Proc. Natl. Acad. Sci. USA, 104, 9741 (2007).

(田中元雅, 理化学研究所脳科学総合研究センター)

\section{ポリリン酸畜䆏菌の機能解明はどこまで進んだか? 新しいリン除去技術の構築に向けての努力とメタゲノム解析}

日本の産業において最む広く利用されている微生物技 術は何か？この質問に正しく答えられる人は残念なが らほとんどいない，その理由は，この技術には微生物の 専門家がほとんど関与しておらず，もっぱら土木工学の 対象になっているからである. 答は,「廃水処理技術」で ある. 産業界では, 食品や薬品の工場だけでなく, 石油, 繊維, パルプなど, ほとんどの業種において廃水処理に は微生物が利用されている。 また, 下水処理場は例外な くすべてが微生物法を採用している. しかし困ったこと に, 廃水処理系には分離培養できない菌が多くて, 微生 物学的なアプローチが非常に難しいのである.

標題のポリリン酸蓄積菌は, 廃水中に含まれているリ ンの除去に活躍する菌である. リンは内洨や湖沼の富栄 養化の原因になるため, 廃水処理の段階で除去すること が必要である. 家庭下水には $4 \sim 6 \mathrm{mg} / l$ のリンが含まれ ていて, 標準的な下水処理ではリンが $40 \%$ ほどしか除 去できないが, 生物学的リン除去法を採用すると, 除去 率が $90 \%$ 以上になり, リン濃度は $0.5 \mathrm{mg} / l$ 以下にな る. しかし時々, リンが $40 \%$ 程度しか除去できないとい う事態が起こる．リンが安定して除去できないのなら， 他の方法, たとえば薬品を使って凝集沈殿でリンを除去 する方法を採用すればよいではないかという意見もある
と思うが, 処理費用を考えると, 生物学的リン除去法が 優れており，30 年以上にわたって用いられている。した がって, この方法で安定したリン除去を実現したいとい う要望は強い。そのためには, まず, リン除去を担う菌 の性質を調べることが重要であるが，その菌の分離培養 が成功せず，したがって菌の分離培養に依存する従来か らの研究方法では, 何の手がかりも得られなかった。

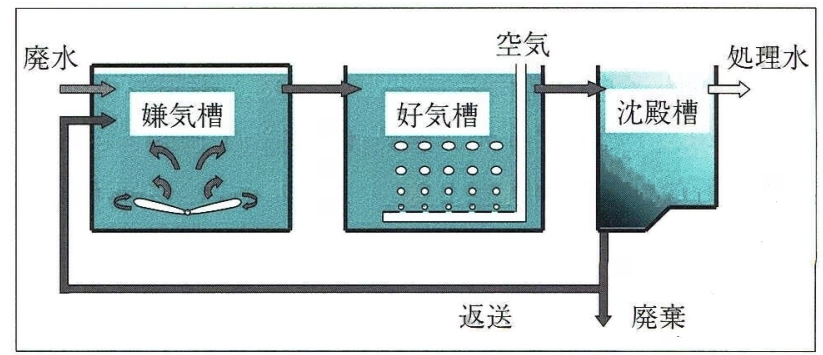

図 1 回生物学的リン除去法の概念図

嫌気槽では, ポリリン酸蓄積菌がポリリン酸を分解しながら有 機物を体内に取り込むので, 有機物濃度が急速に減少し, リン 濃度が増加する. 好気槽では, ポリリン酸蓄積菌が体内の有機 物を分解して増殖するとともにポリリン酸を蓄積するので, リ ン濃度が急速に減少する。 なお, メタン生成菌や硫酸塩還元菌 のような偏性嫌気性菌は,このプロセスではほとんど生育しな い. 
次善の策として分離培養に頼らないアプローチが必要 ということになるが, その話の前に, 生物学的リン除去 法とはどんなものかを簡単に説明しておこう，処理プロ セスは図 1 に示したとおりで, 嫌気好気活性污泥法と呼 ばれるプロセスである。この方法では，まず蓋をした槽 (嫌気槽) に微生物集団と廃水とを入れる. 槽内は酸素が 微生物によってすぐに使い尽くされて, 常に無酸素状態 になっている。この無酸素状態に $2 \sim 3$ 時間おいたあと, 液を次の槽 (好気槽) に入れて, ここでは, 空気を送り 込んで 3 4 時間微生物に酸素を与える（液の滞留時間 がもっと長い場合もある).そのあと, 沈殿槽に 1 時間ほ ど静かに置くと微生物集団が沈降するので，上澄みを河 川などに捨てる，沈降した微生物集団の大部分は嫌気槽 へ戻すが，余分になった分は廃棄する。このときに廃棄 される微生物集団のリン含量が高ければ高いほど，たく さんのリンを除去することができる.

このようなプロセスを使うと，ポリリン酸蓄積菌が集 積される.なぜなら，このプロセスで生存競争に勝ち抜 くためには嫌気槽で多くの有機物を体内に取り込むこと が必要であり，それには，有機物をたくさん取り込むた めのエネルギーを嫌気下でつくり出せる仕組みが必要に なる. ポリリン酸を体内に蓄積しておけば，これを分解 することで有機物を取り込むエネルギーを生み出すこと ができる，こうして嫌気槽で多量に体内に取り込んだ有 機物を好気槽で酸化分解し, 得られたエネルギーでポリ リン酸を合成して体内に蓄積するとともに，増殖して仲 間を増やすのである. ポリリン酸蓄積菌が優占すれば, 微生物集団のリン含量は $0.1 \sim 0.15 \mathrm{gP} / \mathrm{g}$ dry cell に達 し，リンがたくさん除去できるが，グリコーゲンを蓄積 する菌も嫌気槽でエネルギーを生み出して有機物を取り 込めるので, この菌が優占するとリン含量が $0.02 \mathrm{~g} / \mathrm{g}$ ほ どに低下し，リンが少ししか除去できなくなる.

それでは, ポリリン酸蓄積菌を常に安定的に優占させ るためにはどうすればいいのだろうか. 困ったことに, 肝心の菌が分離できず, 菌の詳しい性質がわからなく て，何の手がかりもない，そこで，菌の分離に依存しな い研究方法が用いられた。 まず，微生物集団を FISH (fluorescence in situ hybridization) 法で染めることで, 優占している菌は $\beta-2$ プロテオバクテリアに属すること が明らかになった。次に，微生物集団から DNA を抽出 し，クローンライブラリー法を用いてその中の $16 \mathrm{~S}$ rRNA 遺伝子の塩基配列を解析し, 優占種の $16 \mathrm{~S}$ rRNA
の塩基配列が推定された，そして，この塩基配列をもつ 菌をFISH 法で染色し, 優占菌かどうかが確められ た ${ }^{(1)}$.この一連の実験によって, 優占しているポリリン 酸蓄積菌はRhodocyclus 属に近縁の菌であるとわかり， 'Candidatus Accumulibacter phosphatis' と命名され た。

これで，ポリリン酸蓄積菌の分類学的な性質がわかっ たが, 廃水処理に肝心な生理学的性質はまだ不明であ る. そこで, 次に行なわれたのが, メ夕ゲノム解析で, まず微生物集団から DNA を抽出し，その塩基配列を手 当たり次第に読むことで 'Ca. A. phosphatis' のゲノム の塩基配列のほぼ全容が解明され，次にこの菌の代謝系 を推定するという作業が行なわれた(2). 今後は，このゲ ノム情報を基にしてリン酸の代謝系とその調節系を詳細 に解明していくということであるが，それがどのように リン処理に役立つのかについては，まだ何む示されてい ない。また，この菌には窒素固定に必要な全遺伝子がそ ろっていることや, コバルト要求性があることがわかっ たことに基づき, 無窒素の培地にコバルトを添加して菌 の分離が試みられたが，菌の集積はできてむ，分離には 成功しなかったと報告されている(2).

ところで, 微生物の専門家は, 分離された菌が研究の 出発点であって, 分離できない菌は視野に入っていない ために，菌は分離できて当たり前のように考える傾向が 強いようである。しかし，考えてみるに，35 億年ほど前 に地球上に生命が誕生し, その後の進化の過程では, 常 に周囲に他の種類の生物が存在したわけであって，うま く他の生物を利用したり, 利用されたりという関係が複 雑に絡まっているのが現状であろう。その中で，菌を 1 個だけ分離して, 増殖しろといっても増殖しないのが普 通であって, 微生物学で使っているような分離培養可能 な菌はきわめて例外的ではないかと思えるのである．と はいえ, 菌の分離培養ができないと研究は非常に難し い。

廃水処理関係では，肝心の菌がなかなか分離できてい ない，この菌の他にも，廃水からの窒素除去に有望な嫌 気的アンモニア酸化菌が分離できておらず，これもメタ ゲノム解析が行なわれて, その結果が最近の Nature 誌 に発表された ${ }^{(3)}$.このように, 分離培養できていない菌 についても, ようやく生物学的なアプローチが可能に なってきた，今後の課題は，解読された塩基配列が廃水 処理にどう役立つのかという点である(4). 今後の研究の 
展開を予想するのは難しいが, 生化学分野の研究者の貢 献が期待されていることは間違いない。

1) G. R. Crocetti, P. Hugenholtz, P. L. Bond, A. Schuler, J. Keller, D. Jenkins \& L. L. Blackall : Appl. Environ. Microbiol., 66, 1175 (2000).
2) H. G. Martin et al. : Nature Biotechnol., 24, 1263 (2006).

3) M. Strous et al.: Nature, 440, 790 (2006).

4) T. Mino \& H. Satoh : Nature Biotechnol., 24, 1229 (2006).

(金川貴博*1, 奥貫 優*2, *1京都学園大学バイオ環境学 部, ${ }^{* 2}$ 日鉄環境エンジニアリング(株)）

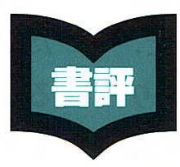

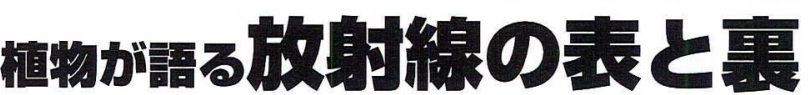 鶴飼保地鹤 \\ 四六判，240 面，3,360 月（㟋远） \\ (株) 蟙風館，2007 年}

レントゲンが X 線を発見してからすでに 112 年が経過 し, 今や放射線は工業, 農業, 医療分野に広く利用され, 私達の生活の向上に役立っている. 実際, 放射線利用産業 の経済規模は原子力発電を上回るまでになっているのであ る. 著者の専門分野である放射線育種については, メンデ ルの法則の再発見からド・フリース，モーガンに至る近代 遺伝学の誕生や，マラーやスタッドラーによる人為突然変 異の発見からスウェーデン学派による放射線育種の誕生に 至る経緯とそこに係る人物像が活き活きと描き出されてお り，物語にぐいぐいひき込まれる楽しさがある．日本で稲 の品種「レイメイ」や梨の品種「ゴールド二十世紀」が誕 生した経緯も興味深い。放射線育種に係わる人なら必読で ある.

しかし，表題にあるように著者の目はそのような放射線 の表舞台だけに向けられているのではない，裏の陰の部分 を鋭く見つめている. 本書の主題はむしろこの陰の部分へ の問題提起なのである.ニールらによる原爆被ばく者の調 查結果の結論は，「被ばく二世への遺伝的影響が統計的に 認められなかった」ということであった。この結論はニー ルらの意図を逸脱して「遺伝的影響は存在しない」とか 「遺伝的影響は心配無用」とまでいわれるようになってき た。しかし，本当にそうだろうか，長崎の原爆で放射線を 受けたイネの集団では次代で多数の突然変異が観察されて いるのである。なぜ植物で観察されてヒトでは観察されな
いのか. 著者はこのニール論文の問題点を克明に解析し， 被ばく次代に突然変異が観察されない理由を遺伝学者とし て論理的に洞察している，それは低線量における突然変異 率の閾值の有無も含めて, 動物では困難であっても植物で は正確に把握できる突然変異への影響に関する知識に基づ いており，充分な説得力がある．本書を読むと，なぜ植物 で蓄積されてきた膨大な知識が原爆被ばく者の遺伝的影響 の解析に役立っていないのかという素朴な疑問が残るくら いだ。原爆被ばく者の遺伝的影響をもう一度見直す上で， 本書は貴重な視点を提起しているといえよう.

広島, 長崎への原爆投下から 62 年目を迎える今年でも, まだ被ばく者支援の問題が残っている。では 100 年経てば 問題は解決するのだろうか，著者の結論は 'NO'である. 原爆やフォールアウトによる被ばくは，人類の遺伝子に負 の遺産を蓄積し続けており，いずれは時限爆弾のように爆 発するだろうと著者は危惧している，たとえ重度の遺伝病 患者が淘汰されるとしても，0.1\%減少するのに 3,000 年は かかるというのである。これはほとんど減らないに等し い. 放射線被ばくの遺伝的影響は人類全体として見机大 問題なのである.

「遺伝的影響は心配無用」といい切る前に冷静に本質を 見極めなければならないことを著者は警告している。

(渡辺 宏) 